Hessayon, A., Jane Lead and her transnational legacy, 2016, Palgrave Macmillan UK, reproduced with permission of Palgrave Macmillan. This extract is taken from the author's original manuscript and has not been edited. The definitive, published, version of record is available here: https://link.springer.com/chapter/10.1057\%2F978-1-137-39614-3_5.

\title{
Jane Lead and the Tradition of Puritan Pastoral Theology
}

Amanda L. Capern

Saints should rejoice in nothing more, than to see a crucified Christ in one another. ${ }^{1}$

The historiography of puritanism has contained a puzzle for some time. While some historians would argue that it is not meaningful to speak of the existence of puritans (or their -ism) after, say, 1660, when the radical impetus of puritan revolution was supposedly brought to a halt, others would agree with John Spurr that there was an evolutionary but continuous tradition of radical Protestantism. ${ }^{2}$ The continuity theory is one in which 'the hotter sort' of Protestants of the Elizabethan church did not disappear with the discontinuation of their name. ${ }^{3}$ Instead, they were succeeded by a late seventeenth-century network of individuals and sects who were keen to preach pure doctrine in their efforts to return the Christian faith to its primitive form and to continue to perform their godliness in public. ${ }^{4}$ In Spurr's analysis the 'good old cause' of the religious civil wars survived both the exportation from England of the Calvinist-Bezan Westminster Confession and the expulsion

\footnotetext{
${ }^{1}$ Jane Lead, The Heavenly Cloud Now Breaking (1681), 17. My thanks go to Colin Davis and Ariel Hessayon for insightful reading of this article and very useful suggestions.

2 John Spurr, 'From Puritanism to Dissent, 1660-1700’ in (eds.) Christopher Durston and Jacqueline Eales, The Culture of English Puritanism 1560-1700 (Basingstoke: Macmillan, 1996), chapters 6-8. For the idea of ‘continuity of Puritanism’ until 1642 see Jacqueline Eales, ‘A Road to Revolution: The Continuity of Puritanism' and for the adjectival concepts of 'puritan revolution', 'puritan rule' and 'radical Puritanism' through to 1660, see John Morrill, ‘The Puritan Revolution’ and David R. Como, 'Radical Puritanism, c. 15581660’, in John Coffey and Paul C. H. Lim (eds.), The Cambridge Companion to Puritanism (Cambridge: Cambridge University Press, 2008), chapters 4, 14 and Christopher Durston, 'Puritan Rule and the Failure of Cultural Revolution, 1645-1660', in Durston and Eales (eds.), The Culture of English Puritanism, chapter 7.

${ }^{3}$ For the origins of Puritanism in a 'hotter sort' of Protestant see Patrick Collinson, The Elizabethan Puritan Movement (Oxford: Clarendon Press, 1967), English Puritanism (London: The Historical Association, 1983) and Godly People: Essays on English Protestantism and Puritanism (London: The Hambledon Press, 1983).

${ }^{4}$ See Ariel Hessayon and David Finnegan (eds.), Varieties of Seventeenth- and Early Eighteenth-Century Radicalism in Context (Farnham: Ashgate, 2011); Alexandra Walsham, 'The godly and popular culture', in Coffey and Lim (eds.), The Cambridge Companion to Puritanism, 277, 286; F. Bremer and E. Rydell, 'Performance Art? Puritans in the Pulpit', History Today, 45:9 (1995), 50-54.
} 
Hessayon, A., Jane Lead and her transnational legacy, 2016, Palgrave Macmillan UK, reproduced with permission of Palgrave Macmillan. This extract is taken from the author's original manuscript and has not been edited. The definitive, published, version of record is available here: https://link.springer.com/chapter/10.1057\%2F978-1-137-39614-3_5.

of godly ministers from the English church in $1662 .{ }^{5}$ In this model, later English puritans or, dissenters and after-dissenters from the Anglican Church - shared certain key beliefs and practices. It has been argued, for example, that Protestant nonconformity had a distinct ecclesiology based on the doctrine of the invisible church and also that there was a continuity of evangelical identity expressed as spiritual witnessing and informal extemporaneous prayer practices. ${ }^{6}$ There are key questions to ask, then, about what ideas gave shape to puritan theology over time. This essay aims to throw light on the origins and afterlife of the ideas of Jane Lead and to demonstrate by this means that the puritan continuity thesis can be upheld and even extended not only chronologically but also geopolitically.

Jane Lead is remembered for three things. The first is that she was one of the main English exponents in print of Jacob Boehme (c. 1575-1624), the German mystic whose cosmological visions from 1600 led to the publication of several influential works, perhaps most notably The Way to Christ (1624). ${ }^{7}$ The second is her association with another English Behmenist, John Pordage, whom she met in August 1673 or 1674 and whose household she subsequently joined. ${ }^{8}$ The third is that she formed, with Ann Bathurst, Francis Lee and Richard Roach, the Philadelphian Society in 1697. The Society, which gained financial backing from Baron Kniphausen, set up a spiritual community in lodgings in Hoxton Square, though it also gathered in several other domestic and public spaces. ${ }^{9}$ Lee and Roach believed equally with Lead and Bathurst in the effectual nature of feminine spiritual agency. Francis Lee, for

\footnotetext{
5 John Spurr, 'Later Stuart Puritanism', in Coffey and Lim (eds.), The Cambridge Companion to Puritanism, chapter 5. For the puritan godly content of civil war politics, see also, John Morrill, 'The Religious Context of the English Civil War', Transactions of the Royal Historical Society, 5 $5^{\text {th }}$ Series, 34 (1984), 155-78.

${ }^{6}$ See Martin Sutherland, Peace, Toleration and Decay: The Ecclesiology of Later Stuart Dissent (Waynesboro, Georgia: Paternoster Press, 2003); Andrew Cambers and Michelle Wolfe, 'Reading, Family Religion and Evangelical Identity in Late Stuart England', Historical Journal, 47:4 (2004), 875, 882.

${ }^{7}$ Ariel Hessayon and Sarah Apetrei (eds.), An Introduction to Jacob Boehme: Four Centuries of Thought and Reception (Abingdon, Oxon. \& New York: Routledge, 2014).

${ }^{8}$ See Ariel Hessayon, 'Pordage, John (bap. 1607, d. 1681)' and 'Pordage, Mary (d. 1668)', ODNB and Sarah Apetrei, Women, Feminism and Religion in Early Enlightenment England (Cambridge: Cambridge University Press, 2010), 191-96.

${ }^{9}$ Sylvia Bowerbank, ‘Lead [née Ward], Jane (1624-1704)’ and ‘Bathurst, Ann (b. c. 1638-d. in or before 1704)’, ODNB; B. J. Gibbons, 'Roach, Richard (1662-1730)', ODNB, and 'Lee Francis (1661-1719), ODNB; Apetrei, Women, Feminism and Religion, 196.
} 
Hessayon, A., Jane Lead and her transnational legacy, 2016, Palgrave Macmillan UK, reproduced with permission of Palgrave Macmillan. This extract is taken from the author's original manuscript and has not been edited. The definitive, published, version of record is available here: https://link.springer.com/chapter/10.1057\%2F978-1-137-39614-3_5.

example, argued that Christ had been born of woman to mediate between God and man after the ejection from paradise. ${ }^{10}$ The feminised spirituality of the Philadelphians was not unique. In Germany Johanna Eleanora Petersen believed in the promises made by God to the daughters of Eve in Genesis 3:15 and used this to make the chiliastic argument that all things would be restored in the last days. ${ }^{11}$ German Pietism promoted female agency in private Bible study meetings which were based in small domestic congregations to bring to life the Spenerian idea of 'little churches within the church' ${ }^{12}$ Jane Lead and the Philadelphians were, therefore, not just part of a longer English puritan tradition, they were also part of what Diarmaid MacCulloch has recently called the Protestant Reformation’s ‘spectrum of radicalisms’ across Europe. ${ }^{13}$

The English radical Protestant (or puritan) tradition from which Lead emerged was essentially Calvinist and, like all puritans, she was intensely interested in personal salvation. During the 1640s her religious beliefs were shaped by hearing the sermons of Tobias Crisp, amongst others, and it can be argued that she was radicalised by the wider spiritual revolution, as well as by dissemination of Boehme’s works by radical publishers and booksellers such as Giles Calvert. ${ }^{14}$ Lead shared the context of religious debate and heightened spiritual expectation with male radical co-religionists in overlapping social networks, and sermon and prayer groups. ${ }^{15}$ She also shared the context with a number of female prophets and visionaries, including Eleanor Davies whose prophetic career gained new currency in the wake of the collapse of the English church. There was also a transatlantic

\footnotetext{
${ }^{10}$ Francis Lee, The Labouring Persons Remembrancer: Or, a Practical Discourse of the Labour of the Body (1690), 7, 14-15.

${ }^{11}$ See Johanna Eleonora Petersen, The Life of Lady Johanna Eleonora Petersen, Written by Herself, ed. Barbara Becker-Cantarino (Chicago: University of Chicago Press, 2005).

${ }^{12}$ Pietist meeting structure followed Philipp Spener's model of the collegia pietatis recommended in Pia Desideria (1675).

${ }^{13}$ Diarmaid MacCulloch, Silence: A Christian History (New York: Penguin, 2013), 144.

${ }^{14}$ For example, The Way to Christ was printed in English in London in 1647, 1654 and 1656. Although John Pordage is regarded as the main follower and conduit of Boehme’s works from the 1650s, there were others such as Durant Hotham and Charles Hotham. See Richard L. Greaves, 'Hotham, Charles (1615-1672)', ODNB, and Gordon Goodwin Gibbons, 'Hotham, Durant (1616/17-1691)’, ODNB. See also Ariel Hessayon, 'Jacob Boehme's Writings during the English Revolution and Afterwards: Their Publication, Dissemination, and Influence', in Hessayon and Apetrei (eds.), An Introduction to Jacob Boehme, chapter 5 and Roger Pooley, 'Crisp, Tobias (1600-1643)’, ODNB.

15 See Ariel Hessayon, 'Winstanley and Baptist Thought', Prose Studies, 36:1 (2014), 22.
} 
Hessayon, A., Jane Lead and her transnational legacy, 2016, Palgrave Macmillan UK, reproduced with permission of Palgrave Macmillan. This extract is taken from the author's original manuscript and has not been edited. The definitive, published, version of record is available here: https://link.springer.com/chapter/10.1057\%2F978-1-137-39614-3_5.

dimension, the support of New England religious exiles being reflected in the prayers of thanksgiving and fasting amongst those saints who returned to Old England to establish congregations in 'the New England way'. ${ }^{16}$ Religious experimentalism undermined the formal authority of the visible church and sacralized informal and domestic space. Ariel Hessayon has uncovered the remarkably complex network that gathered around John Pordage and his Biblical Family between 1649 and 1650. This included the female prophet, Elizabeth Poole, as well as Abiezer Coppe, inspired author of A Fiery Flying Roll. Pordage styled himself as Abraham, the biblical patriarch; his wife, Mary, as Deborah, a mother of Israel. Lead inherited Pordage's Abrahamic vision of an inward household offering salvation to Israel and it can be argued that it was this inward-seeking communitarian and associative behaviour that linked all radical Protestant sects. ${ }^{17}$ Even Eleanor Davies attracted to her estate a group of Diggers, including Gerrard Winstanley who, in 1650, came to hear her preach in a barn that she was the spiritual incarnation of the high priest Melchizedek. ${ }^{18}$

There was a problem inherent in Calvinism - predestination was inescapable. Alexandra Walsham has recently defined English puritanism as 'an affective, evangelical piety rooted in an experimental application of the Calvinist doctrine of predestination' ${ }^{19}$ Experimentalism, of course, engendered a continuous search for truth and authority. Some radical Protestants located both in the Holy Scriptures, while others wished to transcend what MacCulloch has called 'the noise of theological controversy' to wait patiently for the silent workings of the Holy Spirit. ${ }^{20}$ Lead looked for inspiration and truth in the Holy Spirit, though one of the features of her pastoral theology as it developed was that she retained the intellectual remnants of Calvinist predestination alongside ideas acquired from Boehme and Pordage. Her first work - The Heavenly Cloud Now Breaking - was published in 1681, a few months before Pordage's death and while she was facilitating publication of his Theologia Mystica. Pordage's pastoral impulse had actually been to abandon predestination altogether: 'Here is

\footnotetext{
${ }^{16}$ Francis J. Bremer, ‘The Puritan Experiment in New England, 1630-1660’, in Coffey and Lim (eds.), Cambridge Companion to Puritanism, 138.

${ }^{17}$ Hessayon, 'Pordage, John', ODNB, and 'Pordage, Mary', ODNB.

${ }^{18}$ The Complete Works of Gerrard Winstanley, eds. Thomas N. Corns, Ann Hughes and David Lowenstein (Oxford: Oxford University Press, 2009), 'Letter to Lady Eleanor Douglas’, 4 December 1650, vol. ii, 422-9. ${ }^{19}$ Alexandra Walsham, ‘The godly and popular culture’, in Coffey and Lim (eds.), Cambridge Companion to Puritanism, 277.

${ }^{20}$ MacCulloch, Silence, 140-150 quoting from 139.
} 
Hessayon, A., Jane Lead and her transnational legacy, 2016, Palgrave Macmillan UK, reproduced with permission of Palgrave Macmillan. This extract is taken from the author's original manuscript and has not been edited. The definitive, published, version of record is available here: https://link.springer.com/chapter/10.1057\%2F978-1-137-39614-3_5.

no Election of Reprobation takes place amongst these Spirits, as being all of them the Sons of God's Eternal Love'. ${ }^{21}$ However, Lead retained more than echoes of the doctrine of reprobation in her first works. 'The spirit of Daniel came upon me', she said, before prophesying that Prince Michael would defeat the evil monarchy. ${ }^{22}$ This was very similar to Eleanor Davies's use of Daniel 7 in A Warning to the Dragon of 1625, as well as some of Davies’s 1640s works in which she equated Prince Michael not with Charles I but with James I, whose Calvinist credentials were rather more creditable. ${ }^{23}$ Davies's path to salvation lay along a linear chronology - 'the beginning of the Creation to the building of the New Jerusalem, the second comming of Messiah, it shall be seaven Weekes or Seaven Moneths’ and she quantified exactly the number of those saved $(144,000)$, implying a finite number also for the damned. ${ }^{24}$ Lead, however, abandoned linear eschatological thinking in favour of a more spatial imagining of the last days. Of the reprobate she spoke much more obliquely in The Heavenly Cloud than Davies had ever done. Nevertheless the reprobate were there, hiding behind a pseudo-Pelagianism which manifested itself as the saved taking the 'Golden Stone'. ${ }^{25}$ At the end of The Heavenly Cloud Lead admitted that there was a sealed number who were saved and in this way she offered assurance of the glory that awaited the elect if they followed 'the Love-harmony and Spirit of Faith'. ${ }^{26}$ However, she did also say that God's 'Divine Ray' would pass over the reprobate and, indeed, it would 'glide away without making any impression'. ${ }^{27}$

Comparing Jane Lead with Eleanor Davies - the only woman prophet to write more works (if not words) than her - is enlightening. Together they exemplify the way in which shared Calvinist doctrinal roots could lead to seemingly different soteriological positions. Although much has been made of Lead's arrival at a doctrine of universal salvation, she sometimes buried the doctrine of election's logical partner - reprobation - in a language that lent only a visual imagery to God's judgement of the damned and she emphasised the operation of the

\footnotetext{
22 Jane Lead, The Heavenly Cloud Now Breaking (1681), 7-8.

${ }^{24}$ Eleanor Davies, A Warning to the Dragon (1625), 38, 42.

25 Jane Lead, The Heavenly Cloud Now Breaking (1681), 8.

${ }^{26}$ Lead, Heavenly Cloud, 36.

${ }^{27}$ Lead, Heavenly Cloud, sig. $\mathrm{A}^{2}-\mathrm{A}^{3}$.
}

${ }^{21}$ John Pordage, Theologia Mystica, or the Mystic Divinitie of the Eternal Invisibles (1683), 89.

${ }^{23}$ Amanda L. Capern, 'Eleanor Davies and the New Jerusalem', in Julie A. Chappell and Kaley S. Kramer (eds.), Women during the English Reformations: Renegotiating Gender and Religious Identity (Basingstoke: Palgrave, 2014). Eleanor Davies's A Warning to the Dragon (1625) was an exegetical paraphrasing of Daniel 7. 
Hessayon, A., Jane Lead and her transnational legacy, 2016, Palgrave Macmillan UK, reproduced with permission of Palgrave Macmillan. This extract is taken from the author's original manuscript and has not been edited. The definitive, published, version of record is available here: https://link.springer.com/chapter/10.1057\%2F978-1-137-39614-3_5.

Holy Spirit rather than lingering over Daniel 7. Davies’s works, by contrast, always featured descriptions of the tortured fate of the damned and these were rooted in a legalistic Biblical exegesis. However, Davies was not averse to offering some hope (even to the reprobate) and her prophetic theology was actually intended to be pastoral. For example, Davies used the idea of Christ's descent into hell as a way of slipping in double covenant theology - a 'first Adam' to ‘second Adam’ translation of the law into God's promise through Christ's spilt blood. Covenant theology - very much around because of the Westminster Confession offered, according to Davies in 1647, 'the mystery of the general redemption'. ${ }^{28}$ Rather like Winstanley, who proposed 'a heterodox marriage of universal redemption with particular election', Davies spoke of a 'common Salvation', hidden in Christ's retention of the keys to the mystery of death and hell. ${ }^{29}$ Lead's pastoral theology relied on a fine distinction being made between redemption through Christ and salvation through Christ in order to maintain a tenuous link with the doctrine of predestination. For example, Lead also utilized the concept of the power of the keys in The Heavenly Cloud: 'the Prince of the new and Everlasting Covenant' would guide believers 'through the passage-gate of Death' ${ }^{30}$ The First Adam/Second Adam escape clause, then, used by both Lead and Davies, was a way of ameliorating the full impact of double predestination for pastoral purposes and only matters of presentation - legalism versus visual symbolism - created an appearance of totally different theological formulation.

If Lead's theology drew, at least to some extent, on Calvinist covenant theology, where does this leave the appeal and influence of Boehme on her thought? Lead's version of radical Protestantism was arguably what Nabil Matar once defined as a 'doctrine of realised eschatology'. ${ }^{31}$ Eschatological thinking of the exact (and exacting) kind promoted by Eleanor Davies and others was found wanting by some religious visionaries as a form of practical divinity. After all, millenarian thinking could sew its own seeds of doubt. When Davies's first prediction for the end of the temporal world came and went with the execution of William Laud in 1645 , she needed to re-set the date to 1700 . She was not the only one to do this - in 1711 Thomas Beverley’s The Grand Apocalyptic Question made a case post facto for the

\footnotetext{
${ }^{28}$ Eleanor Davies, The Mystery of the General Redemption (1647).

${ }^{29}$ Hessayon, 'Winstanley and Baptist Thought', 21; Davies, The Mystery of the General Redemption, 4-5, 15.

${ }^{30}$ Lead, Heavenly Cloud, 8.

${ }^{31}$ Nabil Matar, 'Sterry, Peter (1613-1672)', ODNB.
} 
Hessayon, A., Jane Lead and her transnational legacy, 2016, Palgrave Macmillan UK, reproduced with permission of Palgrave Macmillan. This extract is taken from the author's original manuscript and has not been edited. The definitive, published, version of record is available here: https://link.springer.com/chapter/10.1057\%2F978-1-137-39614-3_5.

currency of his prediction that the world would end in $1697 .{ }^{32}$ By drawing on Boehme, Lead's pragmatic eschatology could take the form of an elaborate vision of Paradise, one that replaced the old chronologies with a more elastic and spatially (instead of temporally) imagined doctrine of salvation. Nigel Smith has argued that the richness and density of Boehme’s visionary writing lent authenticity to his prophetic message and the same can be said of Lead's writing which appropriated his theology in pastorally-strategic ways. ${ }^{33}$ Lead could also divert attention away from reprobation by claiming to have personally seen and felt God's promise of the union of the invisible church with Christ. The early foundations of this paradisical theology can be seen in both of the works published during Lead's initial, short-lived, writing career between 1681 and 1683. For example, in The Heavenly Cloud Lead vested salvation in 'Christ's Ascension Ladder'. The ladder involved a two-way exchange that effectively removed the passivity inherent in the Calvinist doctrine of election: the elect ascended the ladder and the Holy Trinity descended to join in 'the celebration of the Marriage with the Lamb' ${ }^{34}$ God appeared as a 'Paradisical Body' to meet and greet, in an actual, tangible sense, 'those in whom I will be glorified ... in one Spiritual Body at one Table’. ${ }^{35}$

As all puritan theology was pastoral theology per se, this was rather more forgiving than some formulations, but the more evangelical end of the spectrum of radical Protestantism did struggle to provide Biblical precedents. According to Daniel Neal's The History of the Puritans (1738) a crucial Biblical prophet was John the Baptist because he could be used extensively to demonstrate the value of suffering in the service of God. ${ }^{36}$ John's message gave assurance of election because reprobates were oblivious to God and the Spirit of truth. This left believers free to think they were of the elect because they saw, heard and felt (even channelled) the Holy Spirit. Lead retained the concept of the absoluteness of God's sovereignty (with all that implied), but she stressed, for example, God’s mystery and his

\footnotetext{
${ }^{32}$ William Lamont, ‘The Muggletonians 1652-1979: A “Vertical” Approach’, Past and Present, 99 (1983), 29.

${ }^{33}$ Hessayon and Apetrei (eds.), An Introduction to Jacob Boehme, 7 and Nigel Smith, 'Did Anyone Understand Boehme?', chapter 5.

${ }^{34}$ Lead, Heavenly Cloud, sig. $\mathrm{A}^{2}$.

${ }^{35}$ Lead, Heavenly Cloud, sig. $\mathrm{A}^{2}-\mathrm{A}^{3}$.

${ }^{36}$ Daniel Neal, The History of the Puritans, or, Protestant Nonconformists, From the Death of King Charles I to the Act of Toleration by King William and Queen Mary, in the Year 1689 (London: Printed for Richard Hett, 1738), vol. iv, frontispiece. See also John 15:26 and 16:1-5.
} 
Hessayon, A., Jane Lead and her transnational legacy, 2016, Palgrave Macmillan UK, reproduced with permission of Palgrave Macmillan. This extract is taken from the author's original manuscript and has not been edited. The definitive, published, version of record is available here: https://link.springer.com/chapter/10.1057\%2F978-1-137-39614-3_5.

oneness with eternity. The promises of John ran like a thread through her works. The

Heavenly Cloud led with John's message of resurrection of and in Christ, inviting believers to prepare for ascension to heaven. The work embodied sin in flesh, but carnality was then potentially erased by transformation into spiritual flesh and the mystical spiritual death fused the fate of the elect with that of Christ. The elect experienced 'a new Creation' and became 'the first springing Plants of this new Creation'. ${ }^{37}$ Christ, himself, Lead claimed, had experienced 'a four-fold transmutation in his Heavenly humanity' ${ }^{38}$ The route to spiritual incarnation for humans consequently involved a four-step plan to regeneration, or a process of salvation that could be explained, rather than an arbitrary pre-ordained journey that ended - potentially at least - in eternal death. Paternal elders were central to this narrative. They came 'to full and perfect Age', implying that everyone could attain perfection as they emerged from their spiritual war and the 'Sealing Angels' arrived 'with Viols filled with the Love Oil of the Holy Ghost'. ${ }^{39}$ Some of Lead's imagery was alchemical and linked to traditional and commonly-held principles about the four humours and the transforming effects of distilled cures. In spiritual change effected through the body itself the mystical transformations of Christ's body at Holy Communion were invoked. Those saints who were already 'Ascended and Glorified' would descend for the saints to follow and 'th' Elected Seed shall all be then brought in, Christ then shall reign, and put an end to Sin' ${ }^{40}$ The mystical union was brought about by love, that expression of God's relationship with the elect. This vision, then, of the potential for universal salvation, strengthened by messages of God’s love, co-existed with an older Calvinism.

In The Heavenly Cloud Lead claimed that there would be 'yet more wonder and hidden Things, that have been under a Seal' and that she would be able to reveal details of the 'last Age' guiding the way to 'consummation' of the mystical union. ${ }^{41}$ It was the classic pastoral hook, or the promise of more to come, as the Spirit transported the elect on a journey of 'inward Spiritual Death, Resurrection, Ascension, and Glorification’. ${ }^{42}$ The second work, when it came - The Revelation of Revelations - similarly buried old doctrine behind and

\footnotetext{
${ }^{37}$ Lead, Heavenly Cloud, 34, 37.

${ }^{38}$ Lead, Heavenly Cloud, sig, A2-A3.

${ }^{39}$ Lead, Heavenly Cloud, sig, A3.

${ }^{40}$ Lead, Heavenly Cloud, 36, 40.

${ }^{41}$ Lead, Heavenly Cloud, sig, A3 ${ }^{\mathrm{v}}, 7$.

${ }^{42}$ Lead, Heavenly Cloud, 8.
} 
Hessayon, A., Jane Lead and her transnational legacy, 2016, Palgrave Macmillan UK, reproduced with permission of Palgrave Macmillan. This extract is taken from the author's original manuscript and has not been edited. The definitive, published, version of record is available here: https://link.springer.com/chapter/10.1057\%2F978-1-137-39614-3_5.

within the imagery of new ideas, but it drew on Boehme also to develop a highly feminised language of salvation by introducing the 'Virgin Wisdom' as 'Sophia' for the first time, claiming that when the higher 'priestly order' arrived, 'as to outward Sex, there shall be no distinction'. ${ }^{43}$ The imagined ecclesiology was the 'true Temple' or invisible church of believers. ${ }^{44}$ The walls and liturgical contents of the invisible church were plain, even erased as a visible space, but the imaginative visual landscape of worship was cluttered. The 'Tabernacle Body' was familial and domestic, a place where believers would 'all come to be Kings in God's House, and of his own Family' awaiting Melchizedek and the Ark of the Covenant. ${ }^{45}$ As will be seen, when Lead's thinking developed, the powerful feminine paradigm of maternity and birth (as an antidote to death) emerged to dominate in some of her writing and helped to gender and feminise the narrative of seventeenth-century puritan religious radicalism.

In 1694 Lead embarked upon her second writing career with The Enochian Walks with God. In The Enochian she called herself 'a Spiritual-Traveller Whose Face Towards Mount-Sion Above was Set'. ${ }^{46}$ She told her readers that, like Enoch, they too could walk with God. The language of reaching out to the elect suffused all of her works in the 1690s and the approach was pastorally effective amongst her followers. She spoke of the 'Power of the Everlasting Gospel' and of her personal 'Gift' and 'heavenly Power' to set 'the sure Foundation for both his [Christ's] present and future Appearance in the World'. ${ }^{47}$ Her theology continued to combine Behmenist and Paracelsian ideas with covenant theology. For example, The Tree of Faith of 1696 (which had a title modelled on the third part of Boehme's The Treatise of the Incarnation) spoke of her vision of 'the Eagle-Bird' which nested to hatch a 'great Wonder' and included the concept of 'a pure bright attractive Eye' that would bring together those numbered to be in faith's tree. ${ }^{48}$ Apart from the obvious association of the light with God's saving goodness, the idea of 'the wonder eye of eternity' was first expounded by Boehme in

\footnotetext{
43 Jane Lead, The Revelation of Revelations (1683), 49, 105-7.

${ }^{44}$ Lead, Revelation of Revelations, 104, 114.

${ }^{45}$ Lead, Revelation of Revelations, 67-8.

46 Jane Lead, The Enochian Walks with God (1694), title-page and Introduction.

${ }^{47}$ Lead, Enochian Walks with God, Introduction [2-3].

${ }^{48}$ Lead, The Tree of Faith: or, the Tree of Life, Springing up in the Paradise of God (1696), 14-16.
} 
Hessayon, A., Jane Lead and her transnational legacy, 2016, Palgrave Macmillan UK, reproduced with permission of Palgrave Macmillan. This extract is taken from the author's original manuscript and has not been edited. The definitive, published, version of record is available here: https://link.springer.com/chapter/10.1057\%2F978-1-137-39614-3_5.

1620 and had been repeated in Pordage’s Theologia Mystica. ${ }^{49}$ In another passage of The Tree of Faith she spoke of 'the high and approving Eye' and, later, in The Ascent to the Mount of Vision, in 1699, she again beckoned believers to 'turn thine Eye into that Central Light'. ${ }^{50}$ The eye was everywhere, sometimes figured as 'the Light Orb' from which 'wonders' flowed. ${ }^{51}$ In A Fountain of Gardens - her longest and most well-known work of 1696 - she spoke of ‘the Priestly and Prophetical Kingdom upon the Earth’ which would help believers to 'draw in any Light'. ${ }^{52}$ Lead appeared to include herself in this temporal priestly order: 'I saw in vision, a bright round Ball, pourtraid [portrayed] like a Man’s Face, breaking through a Cloud, and immediately two Stars broke through after it, which were very bright and blazing' 53

Boehme's other central belief - in the Virgin Wisdom - made its way as well into all of Lead's texts of the 1690s. In The Ascent to the Mount of Vision and The Signs of the Times, which also came out in 1699, Lead enumerated and diarised millennial prophecies that were couched in a Behmenist topos. Signs of the Times was framed as a numerically-ordered series of signs, sign XXVI being that 'the Tyde must turn, and the Satanical Powers and Kingdom must give way to the Virgin with her Male-Birth’. ${ }^{54}$ The marriage and birth paradigm was proxy-human, sign XXVIII promising that 'Heaven-born Children' would escape the temporal world to be 'instructed in all the divine Arts in the Royal Court of God their Father, and the new Jerusalem their true Native Mother'. ${ }^{55}$ Thus, Lead blurred the distinction between humanity and the son of God. ${ }^{56}$ The Ascent to the Mount of Vision announced that ‘the Woman Cloathed with the Sun’ will ‘travail ... bringing forth the Man-Child’ and God '[i]n swallowing up all into his Eternal Virgin-Womb ... brings forth distinct Figures in the

\footnotetext{
${ }^{49}$ See, for example, the idea of 'God’s Mystery’ in Jacob Boehme, The Tree of Christian Faith (London: 1654) and the idea of 'the Eternal Nature' and 'Spirit of Eternity himself' in John Pordage, Theologia Mystica (1683).

${ }^{50}$ Lead, Tree of Faith, 6; [Jane Lead], The Ascent to the Mount of Vision (1699), Sig. B.

51 Jane Lead, A Revelation of the Everlasting Gospel Message (1697), 28.

52 Jane Lead, A Fountain of Gardens (1696), 16.

${ }^{53}$ Lead, Fountain of Gardens, 384.

${ }^{54}$ Jane Lead, The Signs of the Times (1699), 16. The construction here was very like the anonymous A Short Survey of the Kingdom of Christ (1699), 47.

${ }^{55}$ Lead, Signs of the Times, 17.

${ }^{56}$ Cf. F. L. Cross and E. A. Livingstone (eds.), The Oxford Dictionary of the Christian Church (Oxford: Oxford University Press, rev. ed. 1990), 1445, 1492.
} 
Hessayon, A., Jane Lead and her transnational legacy, 2016, Palgrave Macmillan UK, reproduced with permission of Palgrave Macmillan. This extract is taken from the author's original manuscript and has not been edited. The definitive, published, version of record is available here: https://link.springer.com/chapter/10.1057\%2F978-1-137-39614-3_5.

Image of his own Glory'. ${ }^{57}$ The link between maternity and the doctrine of election runs through other texts. In The Tree of Faith the doctrine of election was re-cast and feminised as 'a new Birth-Nature' for 'all the Children of God by Faith in Christ Jesus, and so Born from the Virgin-Womb of the Jerusalem-Mother'. ${ }^{58}$ This formulation allowed Luther's first pillar of salvation - faith - to peep through and hinted at the connection between maternity and salvation for all. A Revelation of the Everlasting Gospel Message of 1697 spoke similarly of 'the Eternal Womb’ which gave birth to those possessing the image of God or 'Angelical Essence'. ${ }^{59}$ A Fountain of Gardens turned textual formulations into visual ones by paraphrasing Revelation 12 and speaking of the woman bathed in light giving birth. In this way, Lead collapsed Biblical texts comfortably into Behmenist ideas expressing the notion of the Virgin Wisdom (Sophia) giving birth to the incarnate God in Christ.

Sylvia Bowerbank has argued that Lead's first entry into the 1690s world of print with The Enochian was 'pivotal ... because she went beyond what had been revealed by Boehme to declare the doctrine of apocatastasis, the universal restoration of all creation to its original harmony' ${ }^{60}$ However, if Lead shifted to a Creationist topos to escape the uncomfortable logic of double predestination, she also vested Christ's efficacy in his role as 'the second Adam' ${ }^{61}$ A Revelation of the Everlasting Gospel Message did speak of 'the eternal womb', but it also alluded to the need for God's power to counter 'the dark Abyss' and bring the saved from Lucifer into the light. ${ }^{62}$ Thus, the fate of the damned continued to be referred to obliquely in her later works, just glimpsed occasionally through the opaque filters of her imaginative writing. For example, in The Tree of Faith she warned of a potential collective damnation at the day of judgement: 'O England, England, understand the Day of thy Visitation ... Take care, O England, lest this Star do from thee glide away' ${ }^{63}$ The metaphor she used to hide the doctrine of reprobation was the star over Bethlehem, which 'calleth the Ransomed Ones from all Nations, Languages and Tribes to come to the Brightness of its Rising', but 'Clouds of ignorant Suspicion' over 'the true Heir of the New Jerusalem Mother'

\footnotetext{
57 [Lead], Ascent to Mount of Vision, 28, 35.

${ }^{58}$ Lead, Tree of Faith, 64-66, quotation from 66.

${ }^{59}$ Lead, Revelation of Everlasting Gospel Message, 28-9.

${ }^{60}$ Bowerbank, 'Lead [née Ward], Jane', ODNB.

${ }^{61}$ Lead, Enochian Walks with God, title page, Introduction [3].

${ }^{62}$ Lead, Revelation of Everlasting Gospel Message, 29.

${ }^{63}$ Lead, Tree of Faith, 221 [121].
} 
Hessayon, A., Jane Lead and her transnational legacy, 2016, Palgrave Macmillan UK, reproduced with permission of Palgrave Macmillan. This extract is taken from the author's original manuscript and has not been edited. The definitive, published, version of record is available here: https://link.springer.com/chapter/10.1057\%2F978-1-137-39614-3_5.

could shut out the corrupt as the sand ran out of the 'Glass ... now turn’d up' ${ }^{64}$ The pastoral message lay in Lead's millennial visionary encouragement of unity. In The Messenger of An Universal Peace in 1698 she offered readers the city of Philadelphia and 'the Unity of Philadelphian Love’. 65 'O England, England ... a wonderful Morning-Light is springing', she said, though it was conditional upon joining 'the New Philadelphian Temple'. ${ }^{66}$

It can be argued, then, that one of Lead's key strategies for pastoral success was to embed the idea of promise through an expanded and re-imagined covenant theology. A Revelation of the Gospel Message took as its didactic texts Jeremiah 33:9 and Revelation 21:5 which, read together, offered considerable hope that God intended universal salvation. Although Jeremiah was often used as a text of doom about Jerusalem's ruination and the exile and judgement of the Jews, Lead chose its closing sections to proffer the message about God’s New Covenant. Overturning the Adamic covenant, the new promise wrote the law into the hearts of Jews and gentiles alike and Lead added in parenthesis on the title page 'the whole Race of the Apostacy’ ${ }^{67}$ Judgement was tempered by Revelation 21:5 because of the Biblical promise 'Behold I make All Things New' ${ }^{68}$ This hinted that exile and suffering would end and were not, in themselves, indicative of exclusion from the New Jerusalem. The central argument of A Revelation of the Gospel Message was that sin was not eternal, but removed for all through judgement from Christ's 'Mediatorial Throne'. ${ }^{69}$ The all, however, was a rather elastic and equivocal concept.

Understanding Lead - as with other evangelical Protestants - is to understand that sin and its consequences were frighteningly ineluctable. The beauty of God's covenants was that they could temper the implications of his overwhelming power. Abraham's covenant with God was alluded to repeatedly in Lead's works. In The Tree of Faith she talked of 'the Branches of faith, growing up from the Root and stock of Abraham'. ${ }^{70}$ Her tree of faith was

\footnotetext{
${ }^{64}$ Lead, Tree of Faith, 221 [121].

65 Jane Lead, The Messenger of An Universal Peace (1698), 30.

${ }^{66}$ Lead, Messenger of An Universal Peace, 30-1, 34 and Signs of the Times, sig. A2.

${ }^{67}$ Lead, Revelation of Everlasting Gospel Message, sig. $\mathrm{A}^{1}$. See Cross and Livingstone (eds.), Oxford Dictionary of Christian Church, 730-31.

${ }^{68}$ Lead, Revelation of Everlasting Gospel Message, sig. $\mathrm{A}^{1}$. See Alister E. McGrath, Christianity: An Introduction (Malden, Massachusetts: Blackwell, $2^{\text {nd }}$ ed. 2006), 98-9.

${ }^{69}$ Lead, Revelation of Everlasting Gospel Message, sigs. $\mathrm{A}^{1}-\mathrm{A}^{2} \mathrm{v}$.

${ }^{70}$ Lead, Tree of Faith, 68 and 'To the Reader', sig. A3'.
} 
Hessayon, A., Jane Lead and her transnational legacy, 2016, Palgrave Macmillan UK, reproduced with permission of Palgrave Macmillan. This extract is taken from the author's original manuscript and has not been edited. The definitive, published, version of record is available here: https://link.springer.com/chapter/10.1057\%2F978-1-137-39614-3_5.

genealogical, like the Jesse tree, 'from the very Day of our being born into it'. ${ }^{71}$ Perhaps even more tellingly The Tree of Faith had appended to it The Ark of Faith and in this work she went beyond the usual Calvinist sliding scale of covenantal Old Testament doctrines of salvation - Adamic, Mosaic, Abrahamic - to the Noahic covenant in which God gave assurances, literally, to all human beings. Noah was, according to Lead, 'Heir of the Righteousness which is by Faith'. ${ }^{72}$ Through Noah, the 'Stumbling block even to those who call themselves the Children of Abraham', was removed. ${ }^{73}$ The Ark was built in the paradise of the Virgin Wisdom. In Ascent to the Mount of Vision she spoke of 'healing in the ElijahSpirit, as a Type fore-runing [sic] Christ' and she also pushed this work beyond the covenants of work and grace. ${ }^{74}$ She said the 'first Adam' was given 'Prerogative', but the second, or Christ, not only had vastly more power, he was not given it alone; instead it extended to all those who were 'incorporated into his Life and Nature'. ${ }^{75}$ The concept of the Spirit was essential to this doctrine: the laws 'after the manner of the old Covenant, written in Tables of Stone [Mosaic]' came to an end with Christ 'and so is become a fiery Law in the Spirit of Life [my emphasis], engraven upon the Mind and the Heart; there Springing and Rising according to the pure dictate of the Holy Spirit'. ${ }^{76}$

One of the most arresting features of Lead's writing was her attempt to visualize - even to give a tangible visual form to - paradise and heaven, or those spaces where the elect would be brought to 'a full and perfect Redeemed State' and where 'Life doth lie'. ${ }^{77}$ In A Fountain of Gardens she gave a daily account of what she had seen. On 16 February 1676 she was 'cast upon the Crystalline shore' and told to wait because she could not pass through 'his Borders and land peaceably' in her state of 'Mortal Sensitive Life' 'without commencing War'. ${ }^{78}$ She was called by 'our New-Jerusalem Bride' and ordered to dwell 'by this pure Golden Shore' 'till Times-Number shall be fulfilled' while 'the Earthly angry Sea, which foameth from the deep sense of a Quagmire Center' crashed around in the 'Strife and

\footnotetext{
${ }^{71}$ Lead, Tree of Faith, 66. This passage benefitted from an interesting discussion with my colleague David Crouch.

72 Jane Lead, The Ark of Faith Or a Supplement to the Tree of Faith (1696), title page.

${ }^{73}$ Lead, Ark of Faith, sig. $2^{\mathrm{v}}$, 8.

${ }^{74}$ Lead, Ascent to Mount of Vision, 25.

${ }^{75}$ Lead, Ascent to Mount of Vision, 32.

${ }^{76}$ Lead, Ascent to Mount of Vision, 20.

${ }^{77}$ Lead, Tree of Faith, 13, 4-5, 19-26.

${ }^{78}$ Lead, Fountain of Gardens, vol. I, 126-7.
} 
Hessayon, A., Jane Lead and her transnational legacy, 2016, Palgrave Macmillan UK, reproduced with permission of Palgrave Macmillan. This extract is taken from the author's original manuscript and has not been edited. The definitive, published, version of record is available here: https://link.springer.com/chapter/10.1057\%2F978-1-137-39614-3_5.

Mutiny' that would be consumed by the 'Holy Fire's Breath' ${ }^{79}$ The whole spiritual journey could be seen by her readers and vicariously felt in this passage. Transformation involved the senses: 'This Sensation like the New Song, the New Name, and the White Stone, they only who do experiment ... are able to distinguish' ${ }^{80}$ Religion becomes an empirical science and change can be tasted and touched, in the way that a physician might scrutinize the body. ${ }^{81}$ After all, according to one seventeenth-century tract on the senses 'a cleare sighted Soule' began with 'the Sense of Sinne' and could hear edification because of 'the Soule-ravishing hopes of eternity', smell 'the sweet perfume of an udefiled conscience' and taste 'the apprehension of Gods mercy ... by tasting how sweet hee [God] is’. ${ }^{82}$

The pastoral intent of Lead's message was one shared by all puritan ministers. They hoped to offer the saints the secrets they needed to imagine their journey to paradise. Such secrets were designed to offer the saints assurance that they were close to God and were not of the reprobate. Dissenters claimed a witnessing function which came from their apocalyptic vision of standing together as the elect in the last days. The Quaker women of London, for example, described themselves as 'faithful Witnesses both to God and Man, in our own Gift of Grace, in which God hath and doth own us' ${ }^{83}$ The idea of suffering was vital to this message. All of an evangelical faith spoke and wrote as if they were outsiders and people separated from the reprobate, their very exclusion being a sign of an inward knowledge of God. Samuel Willard's The Child's Portion of 1683 - an early Boston imprint that made its way quickly to London - claimed that 'the Children of God are so little regarded here in the World ...

because the World knows not who they are ... Their glory for the present is within; outwardly they look like other men, they eat, drink, labour, converse in earthly imployments, as others do; the communion which they have with God in all of these, is a secret thing'. ${ }^{84}$ The secrets to salvation were the secrets withheld from the damned. Lead created a personalised dialogue

\footnotetext{
${ }^{79}$ Lead, Fountain of Gardens, vol. I, 128-9.

${ }^{80}$ Lead, Fountain of Gardens, vol. I, 503.

${ }^{81}$ Cf. Mark S. R. Jenner, ‘Tasting Lichfield, Touching China: Sir John Floyer’s Senses’, Historical Journal, 53:3 (2010), 647-70 and Jonathan Reinarz, 'Learning to Use their Senses: Visitors to Voluntary Hospitals in Eighteenth-Century England’, Journal for Eighteenth Century Studies, 35:4 (2012), 505-20.

${ }^{82}$ Ric[hard] Brathwayt [Brathwaite], Essaies upon the Five Senses (2 ${ }^{\text {nd }}$ ed., 1635), 'A Table of Contents', n.p.

${ }^{83}$ Mary Foster et al., A Living Testimony From the Power and Spirit of our Lord Jesus Christ in our Faithful Womens Meeting and Christian Socity [sic] (London: s. n., 1685), 6.

${ }^{84}$ Samuel Willard, The Child's Portion (1683), 66-7 in The Puritans: A Sourcebook of their Writings, 2 vols., eds. Perry Miller \& Thomas H. Johnson (New York: Harper Torchbooks, 1965), I, 369.
} 
Hessayon, A., Jane Lead and her transnational legacy, 2016, Palgrave Macmillan UK, reproduced with permission of Palgrave Macmillan. This extract is taken from the author's original manuscript and has not been edited. The definitive, published, version of record is available here: https://link.springer.com/chapter/10.1057\%2F978-1-137-39614-3_5.

of communion between the Saints above and the Saints below in which she spoke of the several gifts to the saints, such as the gift of revelation and the gift of vision. For Lead these were part of the inheritance from the ‘Glorious Virgin’ or 'She of whom the Lord Christ was born in Flesh'. ${ }^{85}$ The key to Lead's ecclesiology, then, was an invisible church of believers, or saints, that could be made visible by selected prophets - such as herself.

One further feature of Lead's pastoral theology in the 1690s distinguished it from the panoply of late seventeenth-century puritan thought. This was the degree to which she imposed the feminine imaginary on the invisible church of the elect. ${ }^{86}$ Lead borrowed her imagery from Boehme and Pordage, but edged even closer than either of them had done to vesting the potential for salvation in the feminine. Boehme had argued that the life of man, which 'existeth in the Mothers womb', was brought into 'one Spirit with God' ${ }^{87}$ Articulating a similar maternal message Pordage had said that 'Spirits' were fed and nourished by the 'Eternal Mother' whose 'powers are the very Blood, Life and Spirit of Love'. ${ }^{88}$ In The Enochian Lead told her readers that the way to walk like Enoch was under the auspices of the 'Eternal Virgin ... our supernatural Mother' who was responsible for overcoming the lapsed state of Adam and Eve because the 'Virgin-Purity' of her womb 'brought forth, and made manifest in time, Angellical Births again for a new-created Host of spiritual born Creatures, begotten by the Holy Ghost' ${ }^{89}$ Thus Lead collapsed the second Adam into Marian imagery to offer a maternal creationist doctrine of salvation. Later, in A Fountain of Gardens, she used Canticles, or the Song of Songs, to conjure up how this spiritual conception might take place. The elect were 'Watered by the Rivers of Divine Pleasure', she said, in remarkably sexualised language. ${ }^{90}$ For Lead, then, the secrets of the marriage bed, of the domestic and the maternal, endowed her pastoral theology with the power to turn her into a female spiritual leader and in her works we see the female body used as a palimpsest upon which God bestowed his love and offered salvation to the elect, if not really to all.

\footnotetext{
${ }^{85}$ Lead, Enochian Walks with God, 26-9.

${ }^{86}$ Cf. Joan Wallach Scott The Fantasy of Feminist History (Durham and London: Duke University Press, 2011). Scott argues that at the intersection of gender and the symbolic structures of society there lies an historical subjective identity which has no fixed location but depends instead on the imaginary, labile and created self.

${ }^{87}$ Jacob Boehme, The Tree of Christian Faith (London: 1654), 6-7.

${ }^{88}$ Pordage, Theologia Mystica, 88-92.

${ }^{89}$ Lead, Enochian Walks with God, 29.

${ }^{90}$ Lead, Fountain of Gardens, vol. I, frontispiece.
} 
Hessayon, A., Jane Lead and her transnational legacy, 2016, Palgrave Macmillan UK, reproduced with permission of Palgrave Macmillan. This extract is taken from the author's original manuscript and has not been edited. The definitive, published, version of record is available here: https://link.springer.com/chapter/10.1057\%2F978-1-137-39614-3_5.

III

The context of the 1690s is important for explaining Lead's message and its potential appeal to beleaguered nonconformists suffering from persecution in Old England - what Ethan Shagan has characterised as ‘the violence of moderation' after the Act of Toleration - and attempts by the Church of England to 'refashion puritan New England' ${ }^{91}$ Nonconformists of the 1690s suffered from a lack of unity and from their own mortality. After 1695 so many of the remaining ejected ministry of 1662 died that very few of them were left in $1700 .^{92}$ Lodowick Muggleton, the last survivor of the 'two last prophets and witnesses of the spirit', died in 1697 and was seen to the grave by a crowd of 248 people. ${ }^{93}$ The idea of the old puritans came to inform Daniel Neal's The History of the Puritans. Gerontocracy meant that the nonconformist burying ground of Bunhill Fields began to fill and Lead, herself, was to be buried there in 1704. Neal was later to claim that the disparate dissenting groups did all consciously adopt a 'Covenant of Uniformity' and there was certainly an ecumenical drive in the Christian reformation societies that popped up in the 1690s. ${ }^{94}$ Suffering, testimony and preparedness became central motifs in late seventeenth-century puritan writing. The Quakers, for example, reeling from imprisonments in the 1680s, began publishing notes from women's meetings to highlight suffering. Mary Foster's A Living Testimony of 1685 recorded the 'secret Smitings of that Spirit which seeks to Divide and lay Waste the Heritage of God' 95 Appropriating the revelation to John to legitimise the voice and 'peace testimony' of elderly Quaker women, Foster claimed that their suffering stood against the 'vain Talkers', the 'Mockers, Scoffers, Writers and Printers against us' who denied that they stood in the truth

\footnotetext{
${ }^{91}$ Ethan Shagan, 'Beyond Good and Evil: Thinking with Moderates in Early Modern England', Journal of British Studies, 49:3 (2010), 488-513 and The Rule of Moderation: Violence, Religion and the Politics of Restraint in Early Modern England (Cambridge: Cambridge University Press, 2011); Jeremy Gregory, 'Refashioning Puritan New England: The Church of England in British North America, c. 1680 - c. 1770', Transactions of the Royal Historical Society, sixth series, 20 (2010), 85-112.

92 Spurr, 'Later Stuart Puritanism’, in Coffey and Lim (eds.), Cambridge Companion to Puritanism, 89.

${ }^{93}$ Lodowick Muggleton, The Acts of the Witnesses of the Spirit: in Five Parts (1699), title page and 9; Lamont, 'The Muggletonians 1652-1979’, 29 and 'Muggleton, Lodowicke (1609-1698), ODNB.

${ }^{94}$ Neal, History of the Puritans, vols. iv, vii-viii and The History of New England containing an Impartial Account of the Civil and Ecclesiastical Affairs of the Country to the Year of our Lord, 1700, 2 vols. (London: Printed for J. Clare, 1720), vol. I, iii-iv.

${ }^{95}$ Foster et al., A Living Testimony, 1-4.
} 
Hessayon, A., Jane Lead and her transnational legacy, 2016, Palgrave Macmillan UK, reproduced with permission of Palgrave Macmillan. This extract is taken from the author's original manuscript and has not been edited. The definitive, published, version of record is available here: https://link.springer.com/chapter/10.1057\%2F978-1-137-39614-3_5.

and spirit of God as 'the spiritual Eye do see'. ${ }^{96}$ The agency of puritan women had expanded and contracted contingently for at least a hundred years, really, from Ann Lok’s translation of Calvin's sermons in the 1550s through to the Quakers when they organized around the moral agency of Margaret Fell in the 1650s. Male Quakers became genuine co-religionists with women and female agency in the movement waxed and waned according to circumstances. ${ }^{97}$ For some puritan groups in the late seventeenth century the household became the key locus for evangelical identity, just as convents acted as domestic but also political spaces for English Catholic women religious and their kin dispersed networks. ${ }^{98}$ Growing out of late sixteenth-century godly household manuals, familial (including friendship network) puritan worship turned into ‘a very particular form of religious sociability’ involving book collection and communal reading practices. ${ }^{99}$ Familial language in worship blurred the line between inward piety and outward membership of a spiritual household, providing identity to puritan groups as their members collaborated in evangelical worship. One Quaker woman told Charles II that she was 'Christ's Minister' and she warned him in 1660 that his reign would only prosper if he allowed her 'liberty for my own practice of my own Household Ordinances'. ${ }^{100}$ The idea looked backwards to the legitimacy claims of sixteenth-century puritan prophesyings and forwards to eighteenth-century domestic sectarianism. Jane Lead's own anti-formalism was so highly developed that in The Tree of Faith she argued that 'Formal Worships set up by Man, and constituted by Rational Inventions, as a shadow must pass away'.101

Anti-formalist thinking meant that puritans in New England as well as Old England in the late seventeenth century sought to build a New Jerusalem that was not imagined as

\footnotetext{
${ }^{96}$ Foster et al., Living Testimony, 3-7. See also Erin Bell’s analysis of Quaker strategies for cohesion in 'The Early Quakers, the Peace Testimony and Masculinity in England, 1660-1720', Gender and History, 23:2 (2011), 283-300.

${ }^{97}$ See Patrick Collinson, The Elizabethan Puritan Movement (London: Jonathan Cape, 1967), 71 and Kate Peters, Print Culture and the Early Quakers (Cambridge: Cambridge University Press, 2005), 141.

${ }^{98}$ Claire Walker, Gender and Politics in Early Modern Europe: English Convents in France and the Low Countries (Basingstoke: Palgrave, 2003).

${ }^{99}$ Andrew Cambers and Michelle Wolfe, 'Reading, Family Religion and Evangelical Identity in Late Stuart England', Historical Journal, 47:4 (2004), 875-6.

${ }^{100}$ A Strange Prophecie Presented to the Kings most Excellent Majesty, by A Woman-Quaker (all in white) called Ahivah (London: 1660), 1-3.

101 Jane Lead, Tree of Faith, sig. $\mathrm{A}^{3}$.
} 
Hessayon, A., Jane Lead and her transnational legacy, 2016, Palgrave Macmillan UK, reproduced with permission of Palgrave Macmillan. This extract is taken from the author's original manuscript and has not been edited. The definitive, published, version of record is available here: https://link.springer.com/chapter/10.1057\%2F978-1-137-39614-3_5.

possessing denominational or national boundaries. Michael Winship has recently pointed out that the puritans in New England were not building 'a city on a hill' (Mount Sion) to remain separate. They did not expect to remain pure and in splendid isolation from the Old World. ${ }^{102}$ The language of inclusivity was actually exclusive and the suffering that puritans experienced said more about their hopes than their pain. Lead exemplified this. In A Living Funeral Testimony she claimed that she knew and felt 'Internal Communication with the Spirit of Christ' and that it would end her suffering by elevating her spirit to a place - a 'mansion' - of perfection. ${ }^{103}$ Cosmological imagery such as ‘the Globe of Eternity' and God’s 'all-seeing Eye' became ubiquitous themes as Lead reproduced her version of Boehme's flaming eye of God encapsulated within the primum mobile that contained angelical and other eternal spirits. The eye of God was perceived as watching the saints at war during the building of the New Jerusalem. Lead called for peace and unity in 'the latter days' of spiritual warfare. ${ }^{104}$ The drive for unity on the radical fringes of Protestantism can also be seen in the transatlantic nature of the debate in print, for example about the threat of Antichrist during the Salem crisis of 1692 and 1693. ${ }^{105}$ Graduates from Harvard released works in Boston and London simultaneously, Benjamin Harris selling them out of his London Coffee House. ${ }^{106}$ It can be argued that the powerfully paradigmatic 'New England mind', as captured by Perry Miller, was partly predicated on this shared transatlantic eschatology. ${ }^{107}$ Puritans both sides of the

102 Michael Winship, Godly Republicanism: Puritans, Pilgrims, and a City on a Hill (Cambridge, Massachusetts \& London, England: Harvard University Press, 2012), 233.

${ }^{103}$ Cf. Julie Hirst, Jane Leade: Biography of a Seventeenth-Century Mystic (Aldershot, Hampshire \& Burlington, Vermont: Ashgate, 2005), 32-40. See also Nigel Smith, 'Jacob Boehme and the Sects', Perfection Proclaimed: Language and Literature in English Radical Religions 1640-1660 (Oxford: Clarendon Press, 1989), chapter 5.

104 Jane Lead, A Living Funeral Testimony (1702), 27-8.

105 See, for example, Cotton Mather, The Wonders of the Invisible World being an Account of the Tryals of Several Witches lately executed in New-England (1693) and Increase Mather, Cases of Conscience concerning Evil Spirits Impersonating Men (1693). The debate had parallels with that generated a hundred years earlier by Reginald Scot's The Discoverie of Witchcraft of 1584.

${ }^{106}$ Samuel Willard (1640-1707), for example, published multiple works in Boston in the 1680s and 1690s, such as The Child's Portion (1684) and The Doctrine of the Covenant of Redemption (1693) which were printed and distributed in the London Coffee House. See Mark Knights, 'Benjamin Harris (c. 1647-1720)', ODNB.

107 Jeffrey K. Jue, 'Puritan Millenialism in Old and New England’, in Coffey and Lim (eds.), Cambridge Companion to Puritanism, 271; Perry Miller, The New England Mind: The Seventeenth Century (Cambridge, Massachusetts \& London, England: The Belknap Press, 1939, rep. 1982); Bremer, 'Puritan Experiment in New England', in Coffey and Lim (eds.), Cambridge Companion to Puritanism, 131. 
Hessayon, A., Jane Lead and her transnational legacy, 2016, Palgrave Macmillan UK, reproduced with permission of Palgrave Macmillan. This extract is taken from the author's original manuscript and has not been edited. The definitive, published, version of record is available here: https://link.springer.com/chapter/10.1057\%2F978-1-137-39614-3_5.

pond equated personal salvation with the fashioning of a godly community of the elect, wherever the elect happened to be. ${ }^{108}$ The Baxterian idea of the republic of godly Christians 'spiritual and eternal good is the chief part of the common good' - not only eroded the difference between the embodied external and internal self, it also eroded any sense of separation between groups of the godly, separated by continents and oceans, exilic and selfmoderating in reality as well as in their minds. ${ }^{109}$

It can be argued also that the domesticated invisible church eroded the boundaries between the sexed body and the soul. Long before the Shakers unsexed their spirituality through celibacy, the Pordage 'Family' had denounced 'flesh and carnal relations'. ${ }^{110}$ Enlighteningly, Lead's description of John Pordage’s last days entirely erased the distinction between the temporal and the spiritual body. She said he 'put off only the weak and less honourable Bodie, and put on Immortalitie and Glorie'. ${ }^{111}$ Puritan women and men watched each other for signs of transformation in life, but they watched each other even more closely at times of death when Christ seemed not just immanent, but reincarnated in the departing soul. Lead said of Pordage that his 'Soul's Hunger to taste of Death' emulated Christ's endurance in life and descent into hell before resurrection. ${ }^{112}$ Puritan Christological death could have uniquely feminine bodily symptoms. John Batchiler recorded that as Susanna Perwich’s torment intensified she suffered 'convulsive motions ... and risings of the mother' and these were witnessed as signs of her salvation by the other girls around her. ${ }^{113}$ The soul was unsexed, but it was not ungendered. The barriers erected by the sort of rationality that hindered the soul and blocked the word and work of God could be thought to exist in men, but perhaps less so in women. According to Sarah Apetrei 'women were allied to Christ's intellect, which confounded the worldly wisdom so esteemed by rational men'. ${ }^{114}$ Female physiology, which was imagined as spongy and porous, made women more emotional and volatile in bodily

\footnotetext{
${ }^{108}$ Cf. Coffey and Lim, 'Introduction', in idem Cambridge Companion to Puritanism, 3.

${ }^{109}$ Richard Schlatter, Richard Baxter and Puritan Politics (New Brunswick, New Jersey: Rutgers University Press, 1957), 21, 62, 76; Shagan, The Rule of Moderation, 151.

${ }^{110}$ Hessayon, 'Pordage, John'.

111 Jane Lead, 'To the impartial and well-disposed Reader’ in Theologia Mystica, 2.

112 Lead, 'To the Reader' in Theologia Mystica, 3.

113 John Batchiler, The Virgins Pattern (London: 1661), 35.

${ }^{114}$ Apetrei, Women, Feminism and Religion, 247-55 quoting from 255.
} 
Hessayon, A., Jane Lead and her transnational legacy, 2016, Palgrave Macmillan UK, reproduced with permission of Palgrave Macmillan. This extract is taken from the author's original manuscript and has not been edited. The definitive, published, version of record is available here: https://link.springer.com/chapter/10.1057\%2F978-1-137-39614-3_5.

ways. ${ }^{115}$ However, understandings of the gendered soul were not quite as binary as this might seem to suggest. Early-modern people believed the senses could be directed by reason and that knowledge - the key to closeness with God - was arrived at through passion. The faculty of reason was sensate according to Richard Braithwait, directing the soul to 'the best taste' which was 'to distaste sin'. ${ }^{116}$ Apetrei suggests that it 'may be possible to regard this dialectic as part of a process which finally established the association between male qualities and rational thought' ${ }^{117}$ Certainly Roland Knox’s seminal twentieth-century work on Enthusiasm argued that 'enthusiasts' collapsed grace into nature as they abandoned reason and waited for the oracular. ${ }^{118}$ Knox tersely commented that 'the unfettered exercise of the prophetic ministry by the more devout sex [women] can threaten the ordinary decencies of ecclesiastical order'. ${ }^{119}$ The loss of bodily control, the poetic ecstasy and rapture signalled an emotionalism that could only be associated with women in this later binary model. However, if irrationality was sometimes gendered feminine by early-modern people, equally it could become the key for both sexes as they unshackled the doctrine of election from its opposite and unlocked more fully the idea of the operation of the Holy Spirit. Phyllis Mack once pointed out that the concept of Christ's lactating nurture of the elect crept into male as well as female expressions of their relationship with God. ${ }^{120}$ After all, the milk and blood of Christ were just different versions of the same fungible fluid concocted in the liver according to the early-modern humoral system. Rational dissent and rational piety of the emerging Enlightenment may have invoked everything from 'popular Kabbalism' to ‘the hermetic symbol of the quest for eternal life'. ${ }^{121}$ However, in some strands of puritan thought, reason itself was used to insist that the heightened senses were indicative of a state of grace. This led

\footnotetext{
115 Phyllis Mack, Visionary Women: Ecstatic Prophecy in Seventeenth-Century England (Berkeley: University of California Press, 1992), 23, 27. See also Thomas Laqueur, Making Sex: Body and Gender from the Greeks to Freud (Cambridge, Massachusetts, 1990); Anthony Fletcher, Gender Sex and Subordination in England, 15001800 (New Haven \& London: Yale University Press, 1995); Laura Gowing, Common Bodies: Women, Touch and Power in Seventeenth-Century England (London: Yale University Press, 2003).

116 [Rich[ard] Brathwayt [Brathwaite], Essaies upon the Five Senses (1 ${ }^{\text {st }}$ ed., 1620), 48-9.

117 Apetrei, Women, Feminism and Religion, 255.

${ }^{118}$ Roland Knox, Enthusiasm: a Chapter in the History of Religion (Oxford: Clarendon Press, 1950), 3.

${ }^{119}$ Knox, Enthusiasm, 20.

${ }^{120}$ Mack, Visionary Women, passim but especially chapters 1, 9.

${ }^{121}$ Knud Haakonssen (ed.), Enlightenment and Religion: Rational Dissent in Eighteenth-Century Britain (Cambridge: Cambridge University Press, 1996), passim and quoting Iain McCalman, 'New Jerusalems: Prophecy, Dissent and Radical Culture’, in idem, 318; Cf. Apetrei, Women, Feminism and Religion, 194.
} 
Hessayon, A., Jane Lead and her transnational legacy, 2016, Palgrave Macmillan UK, reproduced with permission of Palgrave Macmillan. This extract is taken from the author's original manuscript and has not been edited. The definitive, published, version of record is available here: https://link.springer.com/chapter/10.1057\%2F978-1-137-39614-3_5.

to an anti-rationalist and anti-Cartesian piety that was an intellectual hybridity, one that collapsed science and creationist understandings of nature and constructing religious appeal. $^{122}$

Lead's theology urged transcendence of reason because this made possible the escape from temporal corruption. Her preaching - oral and textual - was designed to be read by believers and unbelievers alike as a performative and embodied escape from human reason. ${ }^{123}$ Loss of control was a vital element of the performance of suffering in the manner of Christ. Lead revealed her 'secret Combates that have followed me hard, to shake my Faith' ${ }^{124}$ Like Jesus she was being tested in the wilderness. In one of her last works - The Wars of David - Lead told her readers that 'the whole Life of a Christian is a perpetual Warfare'. ${ }^{125}$ During the 'warrings in the Soul' man was transported 'from a natural to a spiritual Estate, which at first is legal', though this was followed by the state of grace during which there is 'perpetual War' as the 'Children of Israel' (whom she called the 'Elect Seed') are brought out of bondage. ${ }^{126}$ The bondage included human reason. Therefore, if Lead's was a form of rational dissent, it was predicated on her own claims to salvation through the manifestation of the exact opposite.

Puritan visionaries such as Lead experienced auditory and visual sensory overrides and, as William Lamont once pointed out about the Muggletonians, '[t]heir real world was in the mind'. ${ }^{127}$ When Lead and other puritan prophets of the spiritual age picked up the Bible to speak with God, he actually answered. Tanya Luhrmann has recently pointed out that rationality and irrationality are both part of ordinary lived human experience. ${ }^{128}$ Oral performance of sensory override can be seen, for example, in the simply-expressed Quaker

\footnotetext{
${ }^{122}$ By contrast see Brad Gregory, The Unintended Reformation: How a Religious Revolution Secularized Society (Cambridge, Mass.: Harvard University Press, 2012).

${ }^{123}$ Cf. Alexandra Walsham, 'The godly and popular culture', in Coffey and Lim (eds.), Cambridge Companion to Puritanism, 277, 286.

${ }^{124}$ Lead, Tree of Faith, 3.

125 Jane Lead, The Wars of David and the Peaceable Reign of Solomon (1700), 63.

${ }^{126}$ Lead, Wars of David, 64.

${ }^{127}$ Lamont, 'The Muggletonians', 35.

${ }^{128}$ T. M. Luhrmann, When God Talks Back: Understanding the American Evangelical Relationship with God (New York: Vintage Books, 2012), 236. My thanks to Phyllis Mack for a great discussion around this one enjoyable afternoon.
} 
Hessayon, A., Jane Lead and her transnational legacy, 2016, Palgrave Macmillan UK, reproduced with permission of Palgrave Macmillan. This extract is taken from the author's original manuscript and has not been edited. The definitive, published, version of record is available here: https://link.springer.com/chapter/10.1057\%2F978-1-137-39614-3_5.

theology of walking in the light which manifested itself at times as embodied gushes of verbal violence. Elizabeth Hooton explained it as the power of the Lord literally rising within her body. ${ }^{129}$ Quakers quaked because they physically felt the release of their own sinfulness and this led to ecstasy. Later, in the eighteenth century, Ann Lee turned her body into a Cartesian tabula rasa that invited rejection of corporality in favour of transmogrification into spiritual flesh. ${ }^{130}$ Lee burned with her feminised messianic conviction. She invited Shakers to shake because their oral outbursts of God's word could result in the release of speaking in tongues. The Shakers felt themselves bodily possessed by something elemental, which they often explained in terms used to describe nature, such as wind and fire. They described their collective spiritual ecstasy as becoming like clouds, in motion around one another as if 'agitated with a mighty wind'. ${ }^{131}$ The trembling that preceded their eruption into singing and shouting, chanting, jumping about and pacing the boards with uncontrollably shaking limbs, marked a specific Scriptural rite of passage that expressed 'the indignation of God against all sin' moving on to 'joy at the near prospect of salvation'. ${ }^{132}$ The narrative was scripturally based, but the feminised radicalism of their witnessing for God required that reason be disembodied, de-sexualised and speech-disrupted into a new public transcript. ${ }^{133}$ One Shaker hymn linked this bodily freedom to the celibacy that 'Mother Jane' [Wardley] had encouraged in married couples: 'A few first receiv'd it, | And their lusts forsake; | And soon their inward power | Brought on a mighty shake'. ${ }^{134}$ Members of the Cannon Street household congregation believed that their salvation lay as much in physical manifestation through absence as in wild physical motion. The absence was sex and the physical motion

${ }^{129}$ Mack, Visionary Women, 128-9 citing Emily Manners, Elizabeth Hooton: First Quaker Woman Preacher (1600-1672) (London: Headley Brothers, 1914), 36-7, 49.

130 Julie A. Chappell, Perilous Passages: the Book of Margery Kempe, 1534-1934 (New York: Palgrave Macmillan, 2013), xx-xxxvi; Knox, Enthusiasm, 558-9. Ann Lee was illiterate: Carla Gerona, 'Lee, Ann (17361784), ODNB.

131 [Calvin Green and Seth Young Wells], A Summary View of the Millennial Church, or United Society of Believers (Commonly Called Shakers) (Albany: Packard \& Van Benthuysen, 1823), 5.

132 [Green and Wells], Summary View of the Millennial Church, 5.

${ }^{133}$ See the 'public transcript/hidden transcript' paradigm of James C. Scott, Weapons of the Weak: Everyday Forms of Peasant Resistance (New Haven: Yale University Press, 1985) and John Walter, Crowds and Popular Politics in Early Modern England (Manchester: Manchester University Press, 2006).

134 Terrie Dopp Aamodt, 'Wardley, Jane (fl. 1747-1770)’, ODNB; Seth Young Wells, Millennial Praises: containing a collection of gospel hymns, in four parts; adapted to the day of Christ's second appearing (Hancock: Josiah Tallcott Junior, 1813), 79. 
Hessayon, A., Jane Lead and her transnational legacy, 2016, Palgrave Macmillan UK, reproduced with permission of Palgrave Macmillan. This extract is taken from the author's original manuscript and has not been edited. The definitive, published, version of record is available here: https://link.springer.com/chapter/10.1057\%2F978-1-137-39614-3_5.

was dance: 'For dancing is a sweet employ, | It fills the soul with heavenly joy, | It makes our love and union flow, | As round, and round, and round we go'. ${ }^{135}$ In the familial worship at home, the ecstatic joy felt by the Shakers at their perceived salvation embraced them like a tidal wave: 'At Manchester, in England, This blessed fire began, | And like a flame in stubble, | From house to house it ran'. ${ }^{136}$

The Shakers belonged to the same domestic and anti-rationalist puritan tradition as Jane Lead and the Philadelphians. Like Lead they emphasised John's prophetic message and their covenant beliefs were Noahic: 'When the old world of flesh and blood, | Was swept away by Noah's flood'. ${ }^{137}$ Shaker hymns were also intensely feminine and maternal in their descriptions of spiritual warfare. One of their hymns - recorded later about this deeply secretive and by now American sect - invited singing about 'The Heavenly Bridegroom and Bride' and continued: 'Now Christ is revealed in the woman, | And makes her as pure as the light; | This sets the old serpent a foaming, | But let him come on to the fight'. ${ }^{138}$ The Shakers looked to the prophesy of the two olive trees seen by Zechariah to ask 'Pray do they show us the fitness | Of male and the female in one? ${ }^{\text {, }} 39$ Shaker meetings of ecstatic singing and dancing were punctuated by strict and prosaic domestic routines. Privacy had little value in the Shaker world because it was the collective interiority rather than outward formal arrangements for worship that mattered in their quest to build a sinless utopia. ${ }^{140}$ The Shakers simply ensured that men and women in supervisory roles sat in offices across the hall from one another, communicating the logistics of running sex-segregated dormitories - but not directly opposite, just in case they caught sight of one another's sexed bodies. ${ }^{141}$ Perhaps the

\footnotetext{
135 Wells, Millennial Praises, 69.

${ }^{136}$ Wells, Millennial Praises, 79.

137 Wells, Millennial Praises, 3.

138 Wells, Millennial Praises, 19.

${ }^{139}$ Wells, Millennial Praises, 18-19.

${ }^{140}$ Cf. Lena Cowen Orlin, Locating Privacy in Tudor London (Oxford: Oxford University Press, 2007), 1, 193, chapter 8 especially 324-6 and referring to Alan Sinfield, Faultlines: Cultural Materialism and the Politics of Dissident Reading (Berkeley: University of California Press, 1992), 152-80; Retha Warnicke, 'Private and Public: The Boundaries of Women’s Lives in Early Stuart England’ in Jean R. Brink (ed.), Privileging Gender in Early Modern England, vol. xxiii, Sixteenth Century Essays and Studies (Ann Arbor, Michigan: Edwards Brothers, 1993), 138-9.

${ }^{141}$ From personal observation and information from the docent at the Canterbury Shaker Village in New Hampshire, 4 September 2012.
} 
Hessayon, A., Jane Lead and her transnational legacy, 2016, Palgrave Macmillan UK, reproduced with permission of Palgrave Macmillan. This extract is taken from the author's original manuscript and has not been edited. The definitive, published, version of record is available here: https://link.springer.com/chapter/10.1057\%2F978-1-137-39614-3_5.

one thing that most demonstrates the importance of feminine spiritual leadership to these later puritans was their invention of the automated washing machine in the nineteenth century. After all, as far as the Shakers were concerned a washing machine left more time for God to work through the spiritual agency of women in domestic spaces. ${ }^{142}$

Jane Lead was writing just as radical Protestantism found it necessary to invent the term theodicy to explain away human suffering under an omnipotent God. ${ }^{143}$ A Fountain of Gardens was an extended, complex and reasoning exercise that attempted to release the elect from fear of damnation. This was what all puritans wanted from their pastoral theology. $A$ Fountain of Gardens bent Calvinist doctrine and cemented it to a rhetorically anti-rationalist, ocular and sensate pathway to paradise. ${ }^{144}$ Lead incorporated and extended Boehme's idea of the Virgin Wisdom and combined it with hermeticism and the alchemical, but she liberally and loosely applied covenant theology as well. Deploying covenant theology was a common tactic in puritan works because God's promises - especially to Noah - helped to obscure the full impact of double predestination. Puritan theology emphasised the transforming nature of the spirit as it worked through a much more ancient covenant of grace. ${ }^{145}$ Assurance came in the form of the invisible church, or, in Lead's words, 'the living stones' of the Tabernacle. ${ }^{146}$ The invisible church bound the elect, wherever they were, by erasing the material world at the same time as sacralising multiple (often domestic) places of worship where a sensate worship took place that defied all Cartesian logic. ${ }^{147}$

\footnotetext{
${ }^{142}$ Information about the washing machine from the docent at the Canterbury Shaker Village, 4 September 2012.

${ }^{143}$ Luhrmann, When God Talks Back, 267. The term was coined in 1710 by Gottfried Leibniz (1646-1716), rationalist mathematician and philosopher.

${ }^{144}$ Cf. Christopher Haigh, English Reformations: Religion, Politics, and Society under the Tudors (Oxford: Clarendon Press, 1993).

${ }^{145}$ Cf. Miller, New England Mind, 92-3, 360-2; The Works of Anne Bradstreet, ed. Jeannine Hensley (Cambridge, Massachusetts \& London, England: The Belknap Press, 1967, rep. 2005), xxix, xxxiii, xxxvii. ${ }^{146}$ Lead, Fountain of Gardens, vol. I, 399.

${ }^{147}$ Cf. Nicky Hallett, The Senses in Religious Communities, 1600-1800 (Farnham, Surrey and Burlington, VT: Ashgate, 2013); Matthew Milner, The Senses and the English Reformation (Farnham, Surrey and Burlington, VT: Ashgate, 2011).
} 
Hessayon, A., Jane Lead and her transnational legacy, 2016, Palgrave Macmillan UK, reproduced with permission of Palgrave Macmillan. This extract is taken from the author's original manuscript and has not been edited. The definitive, published, version of record is available here: https://link.springer.com/chapter/10.1057\%2F978-1-137-39614-3_5.

In her penultimate work - A Living Funeral Testimony - Lead offered assurance to 'the Beloved Philadelphian Society' that they were 'gather'd into one Unity of Spirit' ${ }^{148}$ Hers was a world in which the elect benefitted from 'peculiar Providences ... Whereupon chosen out I was, with some other Precious Stones' to win 'the Spiritual Warfare' thrust upon them by 'the Evil one'. ${ }^{149}$ The Philadelphians were saints who surely could rejoice in recognizing Christ in one another. Sophia was there in Lead's message, but Christ remained central and, indeed, Lead was engaged in imagining Christ’s arrival. This extraordinary event could happen just at home and involve a very ordinary-looking ladder. It is this domestic and feminised worship under charismatic female leadership that links Lead and the Philadelphians with later evangelical groups, especially the Shakers. They were the hottest of Protestants. They were also puritans in a long tradition of puritanism. The feminine content of the radical religious narrative lay in Lead's suggestion that the sensation she felt at her transforming knowledge of God was actually a song - a new song. Word was transformed into bel canto and the elect felt, saw, tasted and heard that their souls were sinless and that the sensate worship brought them to a full and embodied knowledge of the passion of Christ. What was significant was not Christ's humanity, but that some of them - the saints - might be merged corporally with Christ. The invisible church stretched across time and place and there were only a few short steps between the ideas of Lead - with her breath-taking imagined paradise - and those of the Shakers as they sang and quaked and danced in whirling circles and revelled in the glory of glossolalia.

\footnotetext{
${ }^{148}$ Lead, Living Funeral Testimony, preface, sig. A².

${ }^{149}$ Lead, A Living Funeral Testimony, 1-2.
} 